ВОЗМОЖНОСТИ МАГНИТНОЛЕВИТАЦИОННОГО

ТРАНСПОРТА ДЛЯ ПОВЫШЕНИЯ СВЯЗНОСТИ ТРАНСПОРТНОЙ СЕТИ ЕВРОПЕЙСКОЙ И ПРИУРАЛЬСКОЙ АРКТИКИ И В ЛОГИСТИЧЕСКИХ ПРОЦЕССАХ ${ }^{1}$

\author{
А. Н. Киселенко, Е. Ю. Сундуков \\ Институт социально-экономических и энергетических проблем Севера \\ Коми научного центра Уральского отделения РАН \\ (Сыктывкар, Россия)
}

\title{
THE POSSIBILITIES OF MAGNETIC LEVITATION TRANSPORT TO INCREASE OF A TRANSPORT NETWORK CONNECTIVITY OF EUROPEAN AND PRIURALSKY ARCTIC AND IN THE LOGISTICS PROCESSES
}

\author{
A. N. Kiselenko, E. Y. Sundukov \\ Institute of Socio-Economic and Energy Problems \\ of the North, Komi Scientific Center Ural Branch \\ of the Russian Academy of Sciences \\ (Syktyvkar, Russia)
}

\begin{abstract}
Введение
Для освоения природных ресурсов Арктики и обеспечения функционирования Северного морского пути необходимо развивать транспортную инфраструктуру, обеспечивающую выходы к северным морским портам. Одним из мероприятий в целях модернизации и развития такой инфраструктуры является разработка и внедрение современных и перспективных транспортных технологий, адаптированных к арктическим условиям [1].

\section{Развитие транспортной сети Европейской и Приуральской Арктики с применением магнитнолевитационных технологий}

Развитие транспортной сети Арктической зоны РФ в последнее время осуществляется за счет выхода на полуостров Ямал [2]. В феврале 2011 года открыто железнодорожное сообщение от станции Обская до станции Карская. К 2019 году ожидается постройка железной дороги от стации Бованенково к порту Сабетта, протяжённость которой превысит 170 км [3].

Согласно Стратегии [4] планируется строительство линий Сосногорск - Индига протяженностью 612 км (с целью развития подходов к новому порту для

\footnotetext{
1 Работа выполнена в рамках проекта №15-15-7-20 "Прогнозирование развития транспортной сети Европейской и Приуральской Арктики в условиях её интенсивного освоения" Комплексной программы УрО РАН на 2015-2017 гг.
} 
транспортировки лесных, минеральных и нефтегазовых ресурсов), Воркута Усть-Кара протяженностью 210 км (для обеспечения выхода из Воркутинского района к Баренцеву морю), Бованенково - Харасавей протяженностью 130 км (обеспечит подходы к новым портовым сооружениям Северного морского пути), Паюта - Новый Порт протяженностью 208 км (для создания подходов к новым портовым сооружениям Обской губы и освоения Новопортовского углеводородного месторождения) и др.

Часть из этих линий необходимо реализовать в эстакадном исполнении с применением технологий, подобных «МагТранСити» [5], но адаптированных к условиям Европейской и Приуральской Арктики. Появление таких технологий создаст условия и для реализации проекта контейнерного сообщения эстакадного типа Ивдель - Сосногорск - Индига [6], протяженностью примерно 1200 км с возможным продолжением от Ивдели до границы с Китаем, а также других транспортных проектов Стратегии [4], реализация которых при традиционном железнодорожном строительстве затруднительна.

\section{Применение транспортных систем на магнитной подвеске в логистических процессах}

Новые магнитнолевитационные технологии эффективно встроятся в логистические процессы. Сочетания крупногабаритных (морской порт - «сухой порт») и малогабаритных («сухой порт» - потребитель) контейнерных систем, применение принципов «матрешки» или «стручка» (один или несколько малых контейнеров в большом контейнере), строительство выносных морских и речных причалов и др. при использовании левитационного оборудования позволят автоматизировать и оптимизировать многие операции в логистических цепях доставки.

\section{Заключение}

Применение магнитнолевитационных технологий эстакадного типа позволит повысить связность транспортной сети Европейской и Приуральской Арктики и эффективность логистических процессов в данном регионе.

\section{Библиографический список}

1. «Стратегия развития Арктической зоны Российской Федерации и обеспечения национальной безопасности на период до 2020 года», утверждённая 20 февраля 2013 г. Президентом России Владимиром Путиным. - Код доступа: http://pro-arctic.ru/20/02/2013/legislation/1925 (дата обращения 25.04.2016).

2. Вылиток А. В. Ямальский коридор - основа транспортной инфраструктуры арктической зоны // Мир транспорта. - 2015. - № 2. - С.130-141.

3. Определен строитель железнодорожного пути «Бованенково - Сабетта» / Сайт Информационного агентства REGNUM [Электронный ресурс]. - Код доступа: http://regnum.ru/news/economy/2049528.html/ (дата обращения 07.01.2016). 
4. Стратегия развития железнодорожного транспорта в Российской Федерации до 2030 года // Справочная правовая система «Консультант плюс» [Электронный ресурс]. - Код доступа: http:/www.consultant.ru/law/hotdocs/34693.html (дата обращения 07.01.2016).

5. Антонов Ю. Ф., Зайцев А. А., Корчагин А. Д., Юдкин В.Ф. Магнитолевитационная технология как транспортная стратегия грузовых и пассажирских перевозок // Магнитнолевитационные транспортные системы и технологии / Труды 2-й Междунар. научн. конф. Санкт-Петербург, 17-20 июня 2014. - Киров: МЦНИП, 2014. - С. 24-50.

6. Киселенко А. Н., Сундуков Е. Ю. Технологии высокоскоростного транспорта для Севера России // Транспортные системы и технологии: сетевой электронный журнал [Электронный ресурс] / Петербургский государственный университет путей сообщения. - СПб: ФГБОУ ВПО ПГУПС, 2015 г. - Вып. 1. - С. 5-12. - URL: http://www.transsyst.ru/files/-1-2015_vse_-pdf.pdf (дата обращения 07.01.2016).

\section{References}

1. «Strategy of development of the Russian Arctic and national security for the period till 2020», approved February 20, 2013 Russian President Vladimir Putin

URL: http://pro-arctic.ru/20/02/2013/legislation/1925 (25/04/2016).

2. Vylitok A. V. Yamal'skiy koridor - osnova transportnoy infrastruktury arkticheskoy zony (The Yamal corridor - a basis of transport infrastructure of the Arctic zone ) Mir transporta (Word of Transport and Transportation Journal), 2015, no. 2, pp. 130-141.

3. Opredelen stroitel zheleznodorozhnogo puti "Bovanenkovo - Sabetta" [The builder of a railway track «Bovanenkovo - Sabetta» is defined]. URL: http://regnum. ru/news/economy/2049528.html/ (07/01/2016).

4. Strategiya razvitiya zheleznodorozhnogo transporta v Rossiyskoy Federatsii do 2030 goda [Strategy of development of railway transport in the Russian Federation till 2030]. URL: http://www.consultant.ru/law/hotdocs/34693.html ((07/01/2016).

5. Antonov Yu. F., Zaytsev A. A., Korchagin A. D. \& Yudkin V. F. Magnitolevitacionnaya tekhnologiya kak transportnaya strategiya gruzovyh i passazhirskih perevozok (Magnetic and Levitation Technology as Transport Strategy of Freight and Passenger Traffic). Trudy 2-j Mezhdunarodnoj nauchnshchj konferencii «Magnitnolevitacionnye transportnye sistemy i tekhnologii»[(Works 2nd Int. sci. conf. «Magnetic and levitation transport systems and technologies»]. Kirov, 2014, pp. 24-50.

6. Kiselenko A. N. \& Sundukov E. Y. Transportnye sistemy i tekhnologii: setevoy elektronnyy zhurnal - Transport systems and technologies: network electronic magazine, St. Petersburg 2015, vol. 1, pp. 5-12. URL: http:/www.transsyst.ru/ files/-1-2015_vse_-pdf.pdf $((07 / 01 / 2016)$. 


\section{Сведения об авторах:}

Киселенко Анатолий Николаевич, e-mail: kiselenko@iespn.komisc.ru Сундуков Евгений Юрьевич, e-mail: translab@iespn.komisc.ru

Information about authors:

Anatoly N. Kiselenko, e-mail: kiselenko@iespn.komisc.ru

Evgeny Yu. Sundukov, e-mail: translab@iespn.komisc.ru

Киселенко Анатолий Николаевич, Сундуков Евгений Юрьевич 